\section{Advertisers in This issue:}

Page No.

\begin{tabular}{lr}
\hline ABB Autoclave & 10 \\
\hline${ }^{*}$ Academic Press & 82 \\
\hline ASM International & 102 \\
\hline AXIC & 11 \\
\hline Burleigh Instruments Inc. & 2 \\
\hline${ }^{*}$ Butterworth Heinemann & 100 \\
\hline Chemical Abstracts & 105 \\
Conductus & 1 \\
\hline
\end{tabular}

${ }^{*}$ CSIRO 88

Digital Instruments 8

*Elsevier Science Publishers $\quad 87,99,103$

Goodfellow $\quad 6$

Gordon and Breach Science Publishers $\quad 93$

* Granville-Phillips

79

High Voltage Engineering/

$\frac{\text { Europa BV }}{\text { Horiba }} \frac{\text { inside front cover }}{97}$

*Huntington back cover

Instron $\quad 9$

Instruments SA/Jobin Yvon $\quad 27$

*Intevac 77

*IOP Publishing 98

*JEOL 18

*Lake Shore Cyrotronics 31

*MDC Vacuum Products Corp.

The Mellen Company, Inc. 7

Micro-Optics Technologies, Inc 14

MIT 97

*National Electrostatics Corp. $\quad 24$

Oxford University Press

*Pergamon Press $\quad 94$

*Perkin Elmer 32

Phillips Electronic Instruments Inc. $\quad 26$

Plasma Science, Inc. ___ 37

Princeton Gamma-Tech, Inc.

*Pure Tech Inc.

Quad Group $\quad 42,81,100$

${ }^{*}$ Quantum Design $\quad \longrightarrow \quad 44$

Rexham Industrial $\quad \frac{12}{23}$

Semicaps inc. $\quad 23$

Siemens $\quad \frac{19}{43}$

Sopra $\frac{43}{22}$

*Staib Instrumente $\quad 54$

*Technical Instrument Co. $\quad 80$

*Tencor Instruments 16

*TopoMetrix inside back cover

*VAT 30

VCH 54,81

*Virginia Semiconductor, Inc. $13,15,17$

*Voltaix, Inc. 20

John Wiley \& Sons $84,95,101$

Carl Zeiss, Inc 21

For free information about the products and services offered in this issue, fill out and mail the Reader Sevice Card, or FAX it to (312) 922-3165.

*Please visit us at the Equipment Exhibit, April 13-15, during the 1993 MRS Spring Meeting in San Francisco. See p. 89

\title{
IUMRS Elects Officers, Reviews Activities
}

The International Union of Materials Research Societies met December 3, 1992, during the 1992 MRS Fall Meeting in Boston, MA. Representatives were there from C-MRS (China), A-MRS (Australia), MRSJ (Japan), MRS-T (Taiwan, China), MRS-I (India), MRS (United States), MRS-K (Korea), and E-MRS (Europe). There was no representative from MRS-Mexico.

The IUMRS officers beginning their twoyear terms in 1993 were announced. The 1992 Vice-President, Paul Siffert, automatically moved into the presidency, while 1992 President R.P.H. Chang became immediate past president. Masao Doyama was elected vice-president and Rodney Ewing was re-elected secretary. Elections for treasurer won't be held for another year, so Shigeyuki Sōmiya continues in that position.

\section{IUMRS-ICA}

As part of IUMRS activities, the IUMRS organizations in Asia (C-MRS, MRS-J, MRS-K, and MRS-T) agreed to have an annual conference in Asia that will be conducted in English. The aim of these International Conferences in Asia (IUMRSICA) is to provide more frequent opportunities for Asian scientists to gather and exchange research developments. The meeting is expected to rotate locations among the Asian groups. The first three conferences will be organized by C-MRS (1993), MRS-T (1994), and MRS-K (1995). The 1993 meeting will take place September 6-10, immediately after the IUMRS International Conference on Advanced Materials in Tokyo, Japan, August 31September 4.

\section{IUMRS-Sponsored Meetings}

Plans for the International Conference on Advanced Materials (ICAM-93) are developing rapidly. Organized by MRS-J, the meeting will comprise at least 37 symposia and will be held August 31-September 4, 1993 in Tokyo, Japan. See the February 1993 MRS Bulletin, p. 52 for more information.

IUMRS-ICA-93, organized this year by C-MRS, will be held September 6-10, 1993, immediately following ICAM-93. This meeting on advanced ceramics, nanophase materials, and surfaces and interfaces will be held on a boat in the Yangtze Gorges. (See the February 1993 MRS Bulletin, p. 52.)

The International Conference on Electronic Materials (ICEM-94) is being organized by MRS-T and will be held jointly with IUMRS-ICA-94 in Hsinchu, Taiwan, October 17-20, 1994. (See the February 1993 MRS Bulletin, p. 53.)

\section{IUMRS Lectureship}

To promote materials education in developing countries, IUMRS has initiated a lectureship award. Selected scholars will receive partial support to give lectures in developing countries, with matching support expected from the host institution. (See the February 1993 MRS Bulletin, p. 53, for application information.)

\section{Adhering Body Activities}

Dinesh Sood reported that A-MRS held its first official committee meeting early in 1992. The Australian group has broad support from at least eight existing societies in that country. A-MRS aims to facilitate communication between IUMRS and Australian organizations with an interest in materials research, and to facilitate communication among the Australian societies through a newsletter. A-MRS also initiates and promotes interdisciplinary materials research meetings and symposia coorganized by existing societies. The first meeting sponsored by A-MRS was the Ion Beam Modification of Materials Meeting in February 1993 in Canberra. A meeting on epitaxial growth of III-V compound semiconductor layers is also being planned for later in 1993.

Dong-Shen Yan reported that C-MRS held a symposium on automobile materials in April 1992, drawing about 100 research scientists, professors, and industrialists. In coordination with the Chinese Society of Metals, C-MRS held the First Pacific Rim International Conference on Advanced Materials and Processing (PRICM-1) in June 1992. The meeting covered the processing, research, and technology of electronic materials, composite materials, and other special and high technology materials. The C-MRS Annual Conference was held December 16-20, in Guangzhou.

Paul Siffert reported on E-MRS, which included the annual Spring and Fall meetings. The Spring Meeting was held in conjunction with the International Conference on Electronic Materials (ICEM-92), an IUMRS-sponsored event. It covered such materials as $\mathrm{Si}-\mathrm{Ge}$ and CdTe, and techniques ranging from fabrication process control to synthetic materials for nonlinear optics and electronics. The Fall Meeting in Strasbourg was held jointly with the f.e.m.s. MatTech East-West Conference and Exhibition on Advanced Materials. It covered superconductors, material under extreme conditions, nanophase materials, biomaterials, and recycling. E-MRS was involved with two studies for the EEC: "Impact of Advanced Materials on the Jobs Qualification by Year 2000" and "Status of 